\title{
AKTIVITAS INHIBITOR ENZIM PENGUBAH ANGIOTENSIN (ACE) DAN ANTIOKSIDAN PEPTIDA KOLAGEN DARI TERIPANG GAMA (Stichopus variegatus)
}

\section{The Activity of Angiotensin Converting Enzyme (ACE) Inhibitor and Collagen Peptide Antioxidant from Gama Sea Cucumber (Stichopus variegatus)}

\author{
M. Habbib Khirzin', Sukarno', N.D. Yuliana', Yusro Nuri Fawzya2 ${ }^{\star}$, dan Ekowati Chasanah² \\ ${ }^{1}$ Departemen IImu dan Teknologi Pangan, Fakultas Teknologi Pertanian, IPB \\ Kampus IPB Dramaga, Bogor, Indonesia \\ ${ }^{2}$ Balai Besar Penelitian dan Pengembangan Pengolahan Produk dan Bioteknologi Kelautan dan Perikanan, \\ JI. K.S. Tubun Petamburan VI, Jakarta Pusat, Indonesia \\ Korespondensi Penulis: nurifawzya@gmail.com
}

Diterima: 8 April 2015; Disetujui: 27 Mei 2015

\begin{abstract}
ABSTRAK
Teripang merupakan salah satu echinodermata yang memiliki kandungan protein tinggi dan sekitar $70 \%$ dari proteinnya merupakan kolagen. Tujuan penelitian ini adalah untuk mengetahui aktivitas inhibitor Angiotensin Converting Enzyme (ACE) dan antioksidan dari peptida kolagen teripang Gama (Stichopus variegatus). Ekstraksi kolagen dilakukan menggunakan asam asetat $0,5 \mathrm{M}$. Peptida kolagen diperoleh melalui hidrolisis kolagen menggunakan enzim pepsin dengan konsentrasi 0,1 U/g kolagen, selama 0; 30; 60; 90; 120; 180; dan 240 menit. Aktivitas inhibitor ACE dan antioksidan peptida kolagen diuji dengan metode spektroskopi. Kolagen yang dihasilkan memiliki rendemen 16,40\% dengan berat molekul 130,33 kDa. Aktivitas inhibitor ACE tertinggi dihasilkan dari proses hidrolisis selama 180 menit dengan penghambatan sebesar 82,31\%, sedangkan aktivitas antioksidan tertinggi dihasilkan oleh peptida kolagen dari hidrolisis kolagen selama 120 menit dengan nilai $\mathrm{IC}_{50} 1,9 \mathrm{mg} / \mathrm{ml}$.
\end{abstract}

KATA KUNCl: teripang, Stichopus variegatus, peptida kolagen, inhibitor ACE, antioksidan

\begin{abstract}
Sea cucumber is one of echinoderms containing a high level of protein, in which $70 \%$ of the protein consists of collagen. The aim of this study was to determine the ACE inhibitor and antioxidant activities of collagen peptide obtained from Gama sea cucumbers (Stichopus variegatus). Collagen was extracted using $0.5 \mathrm{M}$ acetic acid. It was then hydrolized by $0.1 \mathrm{U} / \mathrm{g}$ collagen for 0; 30; 60; 90 ; 120; 180; 240 min to produce collagen peptides. The ACE inhibitor and antioxidant activities of collagen peptides were determined by spectroscopy method. The results showed that the collagen had $16.40 \%$ yield with the molecular weight of $130.33 \mathrm{kDa}$. The highest ACE inhibitor activity was produced by the peptide from hydrolisis process for $180 \mathrm{~min}$. with the inhibition of $82.31 \%$; while the highest antioxidant activity was obtained from $120 \mathrm{~min}$. hydrolysis time with the $I C_{50}$ of $1.9 \mathrm{mg} /$ $m l$.
\end{abstract}

KEYWORDS: sea cucumber, Stichopus variegatus, collagen peptide, ACE inhibitor, antioxidant

\section{PENDAHULUAN}

Teripang merupakan salah satu jenis echinodermata yang diketahui memiliki berbagai bioaktivitas yang bermanfaat untuk kesehatan. Hal ini dikarenakan teripang kaya akan berbagai kandungan zat gizi maupun senyawa bioaktif. Kandungan proteinnya yang tinggi dalam jumlah dan kualitas, berpengaruh dalam menjaga tingkat trigliserida dalam serum darah maupun sistem imun tubuh (Bordbar et al., 2011). Dari total kandungan protein tersebut, sekitar 70\%-nya adalah kolagen. 
Kolagen merupakan salah satu jenis protein struktural penyusun komponen kulit, gigi, tulang, otot, dan rambut. Hidrolisis kolagen secara enzimatis menghasilkan hidrolisat yang mengandung peptida kolagen. Produk ini dilaporkan memiliki bioaktivitas yang bermanfaat untuk kesehatan. Wijesekara et al. (2011) dan Qian et al. (2008) mengungkapkan bahwa peptida kolagen memiliki aktivitas penangkapan radikal bebas (antioksidan) dan penghambatan enzim pengubah angiotensin atau angiotensin converting enzyme inhibitor (ACE inhibitor). ACE merupakan enzim peptidyl-dipeptidase yang mengkatalisis perubahan substrat angiotensin I menjadi angiotensin II. Perubahan ini menyebabkan penyempitan pembuluh darah sehingga tekanan darah menjadi meningkat (hipertensi). Senyawa ACE inhibitor yang banyak digunakan di antaranya adalah captopril dan elanapril (Jimsheena et al., 2010). Sementara itu Vo et al. (2011) yang meneliti peptida gelatin dari ikan nila dan Zhang et al. (2013) yang melakukan eksplorasi terhadap hidrolisat kolagen bovine melaporkan bahwa peptida juga memiliki aktivitas penghambatan ACE karena mampu berikatan dengan sisi aktif enzim ACE dan membentuk molekul kompleks dengan substrat.

Aktivitas antioksidan peptida telah dilaporkan oleh beberapa peneliti, di antaranya adalah Fan et al. (2012) yang melaporkan adanya aktivitas antioksidan pada peptida dari ikan Tilapia (Oreochromis niloticus) hasil hidrolisis menggunakan berbagai protease. Demikian pula Zhou et al. (2012) yang menemukan adanya aktivitas antioksidan pada peptida kolagen dari teripang Stichopus japonicus, sedangkan aktivitas antioksidan peptida dari kerang hijau (Mytilus edulis) dilaporkan oleh Wang et al. (2013).

Beberapa penelitian lainnya terkait dengan kolagen atau peptida kolagen teripang, di antaranya adalah hidrolisat kolagen teripang Stichopus hermaniisebagai bahan pelembab kulit (Andirinasti, 2012); peptida kolagen teripang Apostichopus japonicus dan Cucumaria japonica yang mempunyai bioaktivitas sebagai antitumor, antikoagulan, antiradang dan penyembuh luka (Popov et al., 2013); dan karakterisasi pepsin-solubilized collagen dari Bohadschia spp (Siddiqui et al., 2013).

Kecenderungan masyarakat untuk kembali ke bahan alami karena dinilai lebih aman dibandingkan obat-obat yang umumnya berasal dari senyawa sintetik, mendorong banyaknya penelitian eksplorasi bahan alam termasuk teripang untuk mendapatkan senyawa aktif sebagai bahan obat. Penelitian ini dimaksudkan untuk mendapatkan informasi mengenai bioaktivitas peptida kolagen dari teripang Gama (Stichopus variegatus) sebagai inhibitor ACE dan antioksidan.

\section{BAHAN DAN METODE}

\section{Bahan}

Bahan baku utama yang digunakan dalam penelitian ini yaitu teripang Gama (Stichopus variegatus) yang didapat dari Balai Besar Perikanan Budidaya Laut Lampung. Beberapa bahan pendukung yang digunakan yaitu Tris- $\mathrm{HCl}$, etanol, EDTA (Etylene diamine tetraacetate), $\mathrm{NaOH}$, asam asetat, $\mathrm{NaCl}$, akrilamida, bis-akrilamida, SDS (Sodium Deodecyl Sulphate), TEMED ( $N, N, N, N$ Tetramethylethylenediamine), APS (Ammonium persulphate), glisin, commassive blue, gliserol, merkaptoetanol, metanol, DPPH (2,2-Diphenyl-1Picrilhydrazyl), asam askorbat, HHL (Hippuryl-HistidylLeusine), ACE (Angiotensin-I converting enzyme), captopril, BSA (Bovine Serum Albumin), bufer borat, etil asetat, dan aquabides.

\section{Metode}

\section{Ekstraksi kolagen}

Ekstraksi kolagen didasarkan pada metode Park et al. (2012) dengan beberapa modifikasi. Keseluruhan proses ekstraksi dilakukan pada suhu $4^{\circ} \mathrm{C}$. Teripang segar dicuci kemudian dipotong kecil-kecil dan ditimbang sebanyak 100 gram. Teripang direndam dalam $1000 \mathrm{ml}$ aquades kemudian diaduk (stir) selama 30 menit. Tahapan ini dilakukan sebanyak 2 kali. Selanjutnya teripang direndam dalam $200 \mathrm{ml}$ alkohol $50 \%$ selama 30 menit kemudian dicuci dengan aquades untuk menetralkan $\mathrm{pH}$. Teripang direndam dalam $1000 \mathrm{ml}$ Tris- $\mathrm{HCl}$ 0,1 M dan 4 mM EDTA selama semalam. Selanjutnya, teripang dicuci dengan aquades dan direndam dalam $1000 \mathrm{ml} \mathrm{NaOH} \mathrm{0,1} \mathrm{M}$ selama 2 hari. Teripang kembali dicuci dengan aquades kemudian direndam dalam $1000 \mathrm{ml}$ asam asetat 0,5 M selama 2 hari. Tahapan selanjutnya yaitu penyaringan dengan kain saring kemudian ke dalam filtrat ditambahkan $\mathrm{NaCl}$ dengan konsentrasi $1 \mathrm{M}$ dan didiamkan selama semalam. Suspensi kemudian disentrifuse selama 60 menit $10.000 \mathrm{~g}$. Pelet kolagen yang didapatkan kemudian dilarutkan dalam asam asetat $0,5 \mathrm{M}$ dan didialisis dengan bufer asetat $0,1 \mathrm{M}$ selama semalam. Bufer diganti secara berkala dan terakhir diganti dengan aquades. Kolagen kemudian dibekukan dan dikeringkan dengan freeze dryer.

\section{Hidrolisis dan karakterisasi peptida kolagen}

\section{Hidrolisis kolagen}

Hidrolisis kolagen didasarkan pada metode Zhang et al. (2013) dengan sedikit modifikasi. Sampel 
kolagen sebanyak 1 gram dilarutkan ke dalam 100 $\mathrm{ml}$ buffer $\mathrm{pH} 2,0$ dan diinkubasi pada suhu $37^{\circ} \mathrm{C}$ selama 15 menit. Selanjutnya, 0,1 U enzim pepsin ditambahkan ke dalam sampel kemudian diinkubasi selama 0; 30; 60; 90; 120; 180; dan 240 menit. Reaksi dihentikan dengan pemanasan sampel pada air mendidih selama 5 menit, kemudian didinginkan. Sampel dinetralkan dengan $\mathrm{NaOH} 1 \mathrm{M}$ dan disentrifuse selama 15 menit $10.000 \mathrm{~g}$. Supernatan yang mengandung peptida kolagen, sebagian dibekukan dan sebagian lagi dikeringkan dengan freeze dryer. Supernatan (peptida kolagen) yang dibekukan digunakan untuk analisis derajat hidrolisis (DH), sedangkan peptida kolagen kering beku untuk analisis ACE inhibitor dan antioksidan.

\section{Penentuan derajat hidrolisis}

Derajat hidrolisis kolagen ditentukan berdasarkan metode Silvestree et al. (2013) dengan pengendapan Trichloroacetic acid (TCA) 20\% untuk menghasilkan $10 \%$ fraksi protein terlarut dan $10 \%$ fraksi tidak larut. Sebanyak $500 \mu \mathrm{l}$ sampel peptida kolagen beku yang telah dicairkan (dibiarkan pada suhu ruang) ditambah dengan $500 \mu \mathrm{l} \mathrm{TCA} 20 \%$ kemudian dihomogenkan dan diinkubasi pada suhu $4{ }^{\circ} \mathrm{C}$ selama 30 menit. Selanjutnya campuran disentrifuse $3000 \mathrm{~g}$ selama 20 menit. Kandungan protein terlarut dan protein total dianalisis berdasarkan metode Lowry et al. (1951). Bovine serum albumin (BSA) digunakan sebagai standar. Derajat hidrolisis dihitung dengan rumus:

$\mathrm{DH}(\%)=\frac{\text { Protein terlarut } 10 \% \mathrm{TCA} \times 100}{\text { Total kandungan protein }}$

\section{Penentuan pola peptida kolagen}

Kolagen dan peptida dianalisis polanya menggunakan SDS-PAGE berdasarkan metode Laemmli (1970). Gel pemisah dan gel penahan yang digunakan yaitu 10 dan $4 \%$. Sebanyak $10 \mathrm{mg}$ sampel dilarutkan dalam $0,5 \mathrm{ml}$ SDS $10 \%$ kemudian diinkubasi pada suhu $85^{\circ} \mathrm{C}$ selama 1 jam. Sampel ditambah buffer dan dipanaskan pada suhu $95^{\circ} \mathrm{C}$ selama 5 menit. Selanjutnya, $15 \mu$ sampel dimasukkan ke dalam sumur dan elektroforesis dijalankan ("running") pada tegangan $35 \mathrm{~V}, 15 \mathrm{~mA}$ selama 6 jam. Sebagai penanda protein digunakan marker broad range protein ladder dari Thermo scientific. Gel hasil elektroforesis diwarnai dengan staining solution selama 1 jam kemudian difiksasi dengan destaining solution selama semalam.

\section{Uji aktivitas peptida kolagen}

\section{Uji ACE inhibitor}

Uji ACE inhibitor didasarkan pada metode Arihara et al. (2001). Sebanyak $50 \mu \mathrm{l}$ sampel $(15 \mathrm{mg} / \mathrm{ml})$ ditambah $125 \mu \mathrm{l}$ buffer substrat $(7,6 \mathrm{mM} \mathrm{HHL}$ dan 608 $\mathrm{mM} \mathrm{NaCl}$ dalam $10 \mathrm{ml}$ buffer borat $\mathrm{pH} 8,3$ ). Campuran diinkubasi pada suhu $37^{\circ} \mathrm{C}$ selama 15 menit. Selanjutnya, $50 \mu \mathrm{l}$ enzim ACE $50 \mathrm{mU} / \mathrm{ml}$ ditambahkan pada campuran kemudian diinkubasi selama 30 menit. Reaksi dihentikan dengan penambahan $200 \mu \mathrm{H} \mathrm{HCl} 1$ N. Campuran divortex, ditambah dengan $1140 \mu$ etil asetat kemudian disentrifuse $10.000 \mathrm{~g}$ selama 10 menit. Supernatan sebanyak $1000 \mu \mathrm{l}$ diambil dan dikeringkan pada suhu $95^{\circ} \mathrm{C}$ selama 90 menit. Asam hipurat yang terbentuk dilarutkan ke dalam $1000 \mu \mathrm{l}$ aquabides. Absorbansi diukur pada panjang gelombang $228 \mathrm{~nm}$ menggunakan spektro UV-vis dan sebagai kontrol positif digunakan captopril. Persen penghambatan ACE ditentukan dengan rumus :

$$
\begin{array}{ll}
\text { (\%) penghambatan }=\frac{(A-B)-(C-D)}{(A-B)} & 100 \% \\
\text { Keterangan : } & \text { A (Absorbansi kontrol) } \\
& \text { B (Absorbansi blanko kontrol) } \\
\text { C (Absorbansi sampel) } \\
\text { D (Absorbansi blanko sampel) }
\end{array}
$$

\section{Uji aktivitas antioksidan}

Aktivitas antioksidan diuji berdasarkan metode Li et al. (2006). Sebanyak $10 \mathrm{mg}$ sampel dilarutkan dalam metanol PA kemudian dibuat seri konsentrasi dari 100; 200; 400; 800 ppm. Selanjutnya, $160 \mu \mathrm{l}$ dari tiap seri konsentrasi sampel ditambah dengan $40 \mu \mathrm{l}$ DPPH $(0,3 \mathrm{mg} / \mathrm{ml})$ kemudian diinkubasi pada ruang gelap pada suhu ruang selama 30 menit. Absorbansi diukur pada panjang gelombang $517 \mathrm{~nm}$ dan sebagai kontrol positif digunakan asam askorbat. Konsentrasi sampel dan persen penghambatan diplot ke dalam kurva regresi linier dan nilai inhibition concentration $50\left(\mathrm{IC}_{50}\right)$ dihitung dalam $\mathrm{mg} / \mathrm{ml}$. Persen penghambatan dihitung dengan rumus :

(\%) penghambatan $=\frac{(A-B)-(C-D)}{(A-B)} \times 100 \%$

Keterangan: A (Absorbansi kontrol negatif)

B (Absorbansi blanko)

C (Absorbansi sampel)

D (Absorbansi kontrol sampel) 


\section{Analisis data}

Data hasil penelitian dianalisis menggunakan analisis keragaman (ANOVA) pada taraf $5 \%$ dan uji lanjut Duncan untuk mengetahui pengaruh waktu hidrolisis terhadap aktivitas ACE inhibitor dan antioksidan peptida kolagen.

\section{HASIL DAN BAHASAN}

\section{Ekstraksi Kolagen}

Ekstraksi kolagen merupakan proses yang membutuhkan waktu lama karena sekali proses ekstraksi membutuhkan waktu 7-10 hari. Perbedaan kondisi lingkungan dan jenis teripang yang digunakan menyebabkan hasil penelitian yang didapatkan kurang optimal sehingga dilakukan modifikasi dari metode Park et al. (2012). Kolagen teripang Gama yang diekstrak dengan metode asam (acid soluble collagen) memberikan hasil rendemen sebesar $16,40 \%$ (berat kering atau bk). Abedin et al. (2013); Park et al. (2012); dan Liu et al. (2011) melaporkan bahwa kolagen teripang yang diekstrak menggunakan metode PSC (Pepsin Soluble Collagen) menghasilkan rendemen berturut-turut sebesar 21,3\% (bk); 26,6\% (bk); dan 20,8\% (bk). Gambar teripang segar dan kolagennya disajikan pada Gambar 1.

\section{Hidrolisis dan Karakterisasi Peptida Kolagen}

\section{Derajat hidrolisis}

Derajat hidrolisis dapat dijadikan sebagai indikator keberhasilan proses hidrolisis. Persentase derajat hidrolisis peptida kolagen teripang Gama disajikan pada Gambar 2. Persentase derajat hidrolisis yang didapat dari hasil penelitian yaitu mulai dari waktu 0; 30; 60; 90; 120; 180; dan 240 menit berturut-turut sebesar $0 ; 21,39 ; 36,29 ; 44,79 ; 54,61 ; 54,54$; dan $54,23 \%$. Derajat hidrolisis tertinggi didapat dari waktu inkubasi 120 menit yaitu sebesar 54,61\%. Semakin lama waktu hidrolisis, maka semakin meningkat persen derajat hidrolisisnya. Akan tetapi, setelah 120 menit reaksi berjalan stabil dan tidak ada peningkatan yang signifikan. Kondisi konstan ini diduga karena substrat telah habis dipotong oleh enzim sehingga jumlah peptida yang dihasilkan tetap dan enzim telah jenuh terhadap substrat.

Peningkatan derajat hidrolisis disebabkan oleh peningkatan peptida dan asam amino yang terlarut dalam TCA akibat pemutusan ikatan peptida selama hidrolisis. Selain faktor tersebut, konsentrasi enzim, waktu hidrolisis, serta jenis enzim juga menyebabkan terjadinya perbedaan persen derajat hidrolisis (Haslaniza et al., 2010). Derajat hidrolisis meningkat lebih cepat pada 2 jam pertama, setelah itu semakin melambat. Kecepatan peningkatan derajat hidrolisis yang semakin menurun dapat disebabkan oleh adanya penghambatan proses hidrolisis substrat oleh produk yang dihasilkan selama proses hidrolisis (Ovissipour et al., 2010). Penggunaan enzim pepsin untuk hidrolisis daging ikan tuna (Qian et al., 2008), dan ikan salmon (Kim \& Byun, 2012) dilaporkan menghasilkan hidrolisat dengan derajat hidrolisis sebesar $78,82 \%$ dan $49,12 \%$.

Enzim pepsin merupakan kelompok aspartic protease, yaitu enzim yang memiliki sisi aktif berupa asam aspartat. Pepsin juga termasuk dalam kelompok endopeptidase yang memutus ikatan peptida spesifik pada bagian tengah rantai polipeptida. Pepsin merupakan satu dari tiga jenis enzim pemecah protein (proteolitik) dalam saluran pencernaan, di samping tripsin dan $\alpha$-kemotripsin (Kim \& Byun, 2012).
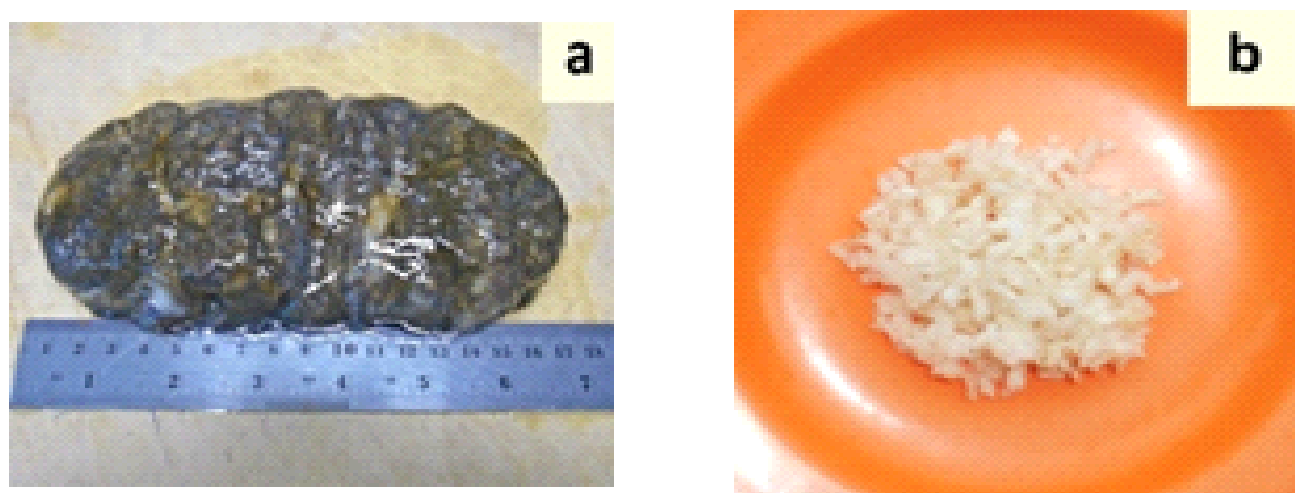

Gambar 1. (a) teripang segar; (b) kolagen teripang.

Figure 1. (a) Fresh sea cucumber; (b) collagen of sea cucumber. 


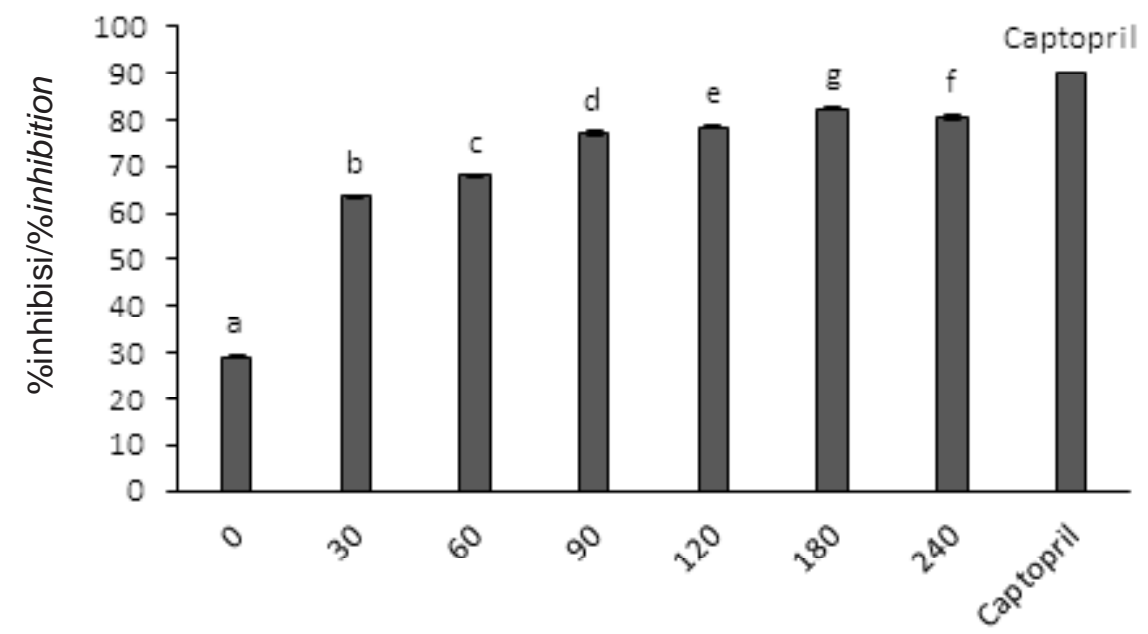

Waktu hidrolisis (menit)/Hydrolisis time (minutes)

Keterangan/Note :

Konsentrasi Captopril/Captopril concentration : $1 \mathrm{mg} / \mathrm{ml}$

Konsentrasi sampel/sample concentration : $15 \mathrm{mg} / \mathrm{ml}$

0 menit/0 minute : tanpa enzim/without enzyme

Gambar 2. Derajat hidrolisis kolagen teripang.

Figure 2. Hydrolysis degree of collagen from sea cucumber.

\section{Pola peptida kolagen}

Kolagen teripang Gama yang masih utuh dan peptidanya dianalisis berat molekulnya menggunakan instrumen SDS-PAGE. Pola elektroforesisnya disajikan pada Gambar 3. Konsentrasi protein yang digunakan adalah $10 \mathrm{mg} / \mathrm{ml}$ dengan perbandingan sampel dan bufer sampel sebesar 4:1. Hasil analisis menunjukkan bahwa kolagen teripang gama memiliki berat molekul sebesar 130,33 kDa, yang merupakan rantai triple helix dan termasuk kolagen tipe I. Saito et al. (2002) menyebutkan bahwa kolagen tipe I biasanya tersusun dari heterolog rantai $\alpha_{1}$ dan $\alpha_{2}$ membentuk triple helix $\left(\alpha_{1}\right)_{2} \alpha_{2}$, di mana komponen berat molekul tinggi $\beta$ dan $\gamma$ merupakan dimer dan trimer dari rantai $\alpha$.

Menurut Zhong et al. (2015), penambahan 2merkaptoetanol tidak memberikan perbedaan yang signifikan karena kolagen teripang tidak mengandung

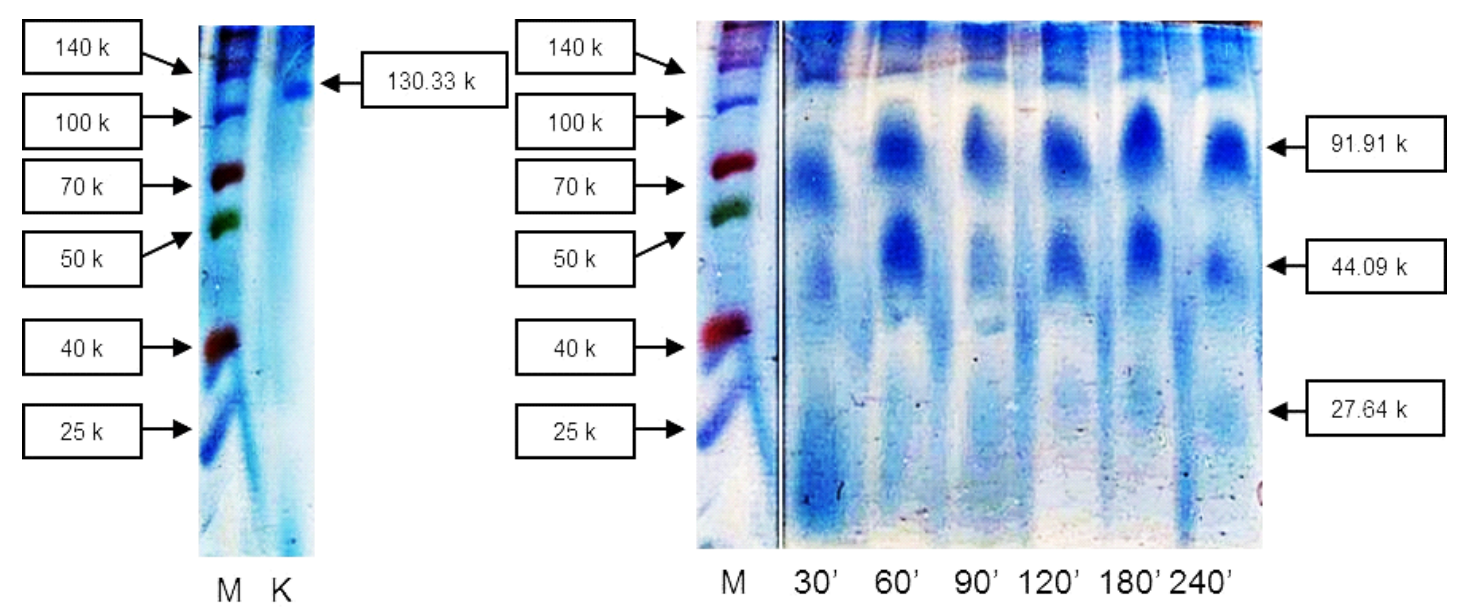

Gambar 3. Pola hidrolisis kolagen oleh enzim pepsin dengan aktivitas $0.1 \mathrm{U}(\mathrm{M}=$ marker, $\mathrm{K}=$ kolagen tanpa hidrolisis).

Figure 3. Hydrolisis pattern of collagen by pepsin enzyme with unit activity $0.1 \mathrm{U}(\mathrm{M}=$ marker, $K=$ Collagen without hydrolysis treatment). 
asam amino sistein sehingga tidak ada ikatan disulfida yang terputus. Ditinjau dari aspek berat molekul, teripang Gama $(130,33 \mathrm{kDa})$ menunjukkan berat molekul rantai $\alpha_{1}$ yang serupa dengan Stichopus monotuberculatos (137 kDa; Zhong et al., 2015), Stichopus japonicus (135 kDa; Cui et al., 2007), dan Parastichopus californicus (138 kDa; Liu et al., 2010).

Kolagen teripang yang telah dihidrolisis dengan enzim pepsin menghasilkan peptida-peptida dengan berat molekul yang lebih rendah. Waktu hidrolisis yang semakin lama menghasilkan peptida dengan ukuran yang lebih kecil. Kolagen yang terpotong dari 30 menit hingga 240 menit sebagian besar menghasilkan 3 fraksi peptida dengan berat molekul yang bervariasi. Peptida yang pertama memiliki berat molekul antara 91,91-95,03 kDa, peptida kedua memiliki berat molekul antara 42,06-47,14 kDa sedangkan peptida ketiga memiliki berat molekul antara 24,1-29,55 kDa.

Pola potongan peptida yang dihasilkan berhubungan erat dengan jenis, konsentrasi dan spesifisitas enzim terhadap substrat yang digunakan. Enzim pepsin yang termasuk jenis protease aspartat, bekerja secara spesifik terhadap asam amino fenilalanin, tirosin, dan triptofan. Secara umum, peptida yang dihasilkan masih tergolong besar karena berat molekulnya berkisar dari $24 \mathrm{kDa}$ hingga $95 \mathrm{kDa}$. Menurut Zhang et al. (2013) di dalam kolagen hanya terdapat sedikit situs pemotongan yang sesuai dengan sisi aktif enzim pepsin sehingga potongan peptida yang dihasilkan berukuran besar.

\section{Uji Aktivitas Peptida Kolagen}

\section{Uji aktivitas ACE inhibitor}

Uji aktivitas ACE inhibitor bertujuan untuk mengetahui aktivitas penghambatan peptida kolagen terhadap enzim ACE yang dinyatakan dalam bentuk persen penghambatan. Aktivitas penghambatan ACE peptida kolagen disajikan pada Gambar 4. Berdasarkan hasil penelitian dapat diketahui bahwa sampel peptida kolagen hasil hidrolisis selama $0 ; 30$; 60; 90; 120; 180; dan 240 menit, memiliki persentase penghambatan ACE berturut-turut sebesar 29,23; 63,$59 ; 67,93 ; 77,00 ; 78,58 ; 82,31$; dan 80,49\% (hasil dari dua kali ulangan). Hasil penelitian tersebut mengindikasikan bahwa semakin lama waktu hidrolisis, persentase penghambatan peptida kolagen terhadap ACE semakin meningkat. Akan tetapi, setelah 180 menit persentase penghambatan ACE mengalami penurunan. Penurunan ini diduga karena peptida terpotong menjadi lebih kecil sehingga peptida yang semula aktif mengalami penurunan aktivitas.

Perbedaan lama waktu hidrolisis memberikan pengaruh yang berbeda secara nyata $(P<0,05)$ terhadap persen penghambatan ACE yang dihasilkan. Uji lanjut Duncan menunjukkan masing-masing waktu hidrolisis berbeda nyata satu sama lain (Gambar 4). Kontrol positif yang digunakan dalam penelitian ini adalah captopril. Captopril dengan konsentrasi $1 \mathrm{mg} /$ $\mathrm{ml}$ memiliki persen penghambatan ACE sebesar

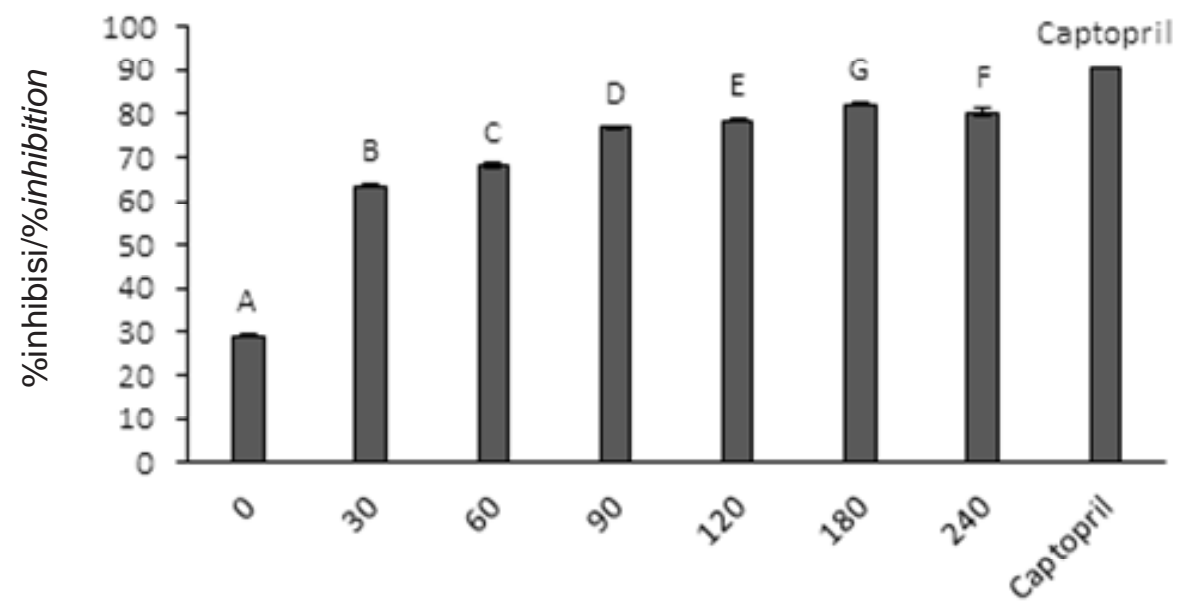

Waktu hidrolisis (menit)/Hydrolisis time (minutes)

Keterangan/Note :

Konsentrasi Captopril/Captopril concentration : $1 \mathrm{mg} / \mathrm{ml}$

Konsentrasi sampel/sample concentration : $15 \mathrm{mg} / \mathrm{ml}$

0 menit/0 minute : tanpa enzim/without enzyme

Gambar 4. Aktivitas ACE inhibitor peptida kolagen.

Figure 4. ACE inhibitor activity of collagen peptide. 
90,32\%. Apabila dibandingkan dengan kontrol positif, peptida kolagen memiliki persen penghambatan yang lebih rendah. Hal ini dikarenakan sampel peptida kolagen masih dalam bentuk peptida kasar (crude).

Aktivitas penghambatan ACE peptida kolagen diduga karena tingginya residu asam amino hidrofobik seperti prolin, alanin dan asam amino alifatik seperti glisin. Menurut Kapel et al. (2006) peptida yang memiliki prolin atau residu aromatis pada ujung terminal-C dan residu asam amino hidrofobik pada ujung terminal-N memiliki aktivitas penghambatan ACE yang potensial. Peptida bioaktif biasanya mengandung 3-20 residu asam amino dengan berat molekul yang rendah. Menurut Wijesekara et al. (2011) aktivitas penghambatan ACE memiliki 2 mekanisme yaitu bersifat kompetitif dan nonkompetitif. Inhibitor kompetitif mampu masuk ke dalam molekul protein ACE dan berinteraksi dengan sisi aktif enzim sedangkan inhibitor nonkompetitif bekerja dengan cara bergabung dengan molekul enzim ACE dan membentuk dead-end complex, terlepas dari apakah molekul substrat berikatan atau tidak.

Beberapa penelitian lain melaporkan hal yang serupa. Vo et al. (2011), menemukan bahwa gelatin kulit ikan nila yang dihidrolisis dengan enzim pepsin selama 4 jam menghasilkan persentase penghambatan terhadap ACE sebesar $45 \%$. Hidrolisis kolagen sapi (Zhang et al., 2013), dan kolagen teripang (Du et al., 2013) dengan jenis enzim dan waktu hidrolisis yang sama, menghasilkan persen penghambatan terhadap ACE masing-masing sebesar 70 dan $74 \%$.

\section{Aktivitas antioksidan}

Aktivitas antioksidan peptida kolagen disajikan pada Gambar 5. Nilai $I_{50}$ didefinisikan sebagai konsentrasi hidrolisat (sampel) yang dibutuhkan untuk menghambat $50 \%$ radikal bebas DPPH. Berdasarkan hasil penelitian dapat diketahui nilai $\mathrm{IC}_{50}$ peptida kolagen dari $0 ; 30 ; 60 ; 90 ; 120 ; 180$; dan 240 menit berturut-turut yaitu 3,$67 ; 3,31 ; 2,72 ; 2,51 ; 1,90 ; 2,12$ dan $2,19 \mathrm{mg} / \mathrm{ml}$. Hasil penelitian tersebut mengindikasikan bahwa semakin lama waktu hidrolisis, maka nilai $\mathrm{IC}_{50}$ semakin menurun. Akan tetapi, setelah 120 menit perbedaannya tidak terlalu signifikan. Perbedaan lama waktu hidrolisis memberikan pengaruh yang nyata $(p<0,05)$ terhadap nilai $I_{50}$ yang dihasilkan.

Uji lanjut Duncan menunjukkan bahwa masingmasing waktu hidrolisis berbeda nyata satu sama lain, kecuali waktu hidrolisis selama 180 menit dan 240 menit (Gambar 5). Semakin rendah nilai IC ${ }_{50}$, maka semakin tinggi aktivitas penangkalan radikal bebas DPPH oleh sampel. Kontrol positif yang digunakan sebagai pembanding dalam penelitian ini adalah asam askorbat (vitamin C). Nilai IC ${ }_{50}$ asam askorbat yaitu $0,01 \mathrm{mg} / \mathrm{ml}$. Apabila dibandingkan dengan kontrol positif, nilai $\mathrm{IC}_{50}$ dari peptida kolagen masih jauh lebih tinggi, sekitar 200-350 kali. Salah satu penyebabnya diduga karena peptida kolagen yang dihasilkan masih dalam bentuk kasar, berupa hidrolisat kolagen yang mengandung beberapa peptida dengan bobot molekul yang berbeda (91,91-95,03 kDa; 42,06-47,14 kDa dan 24,1-29,55 kDa) seperti tampak pada Gambar 3.

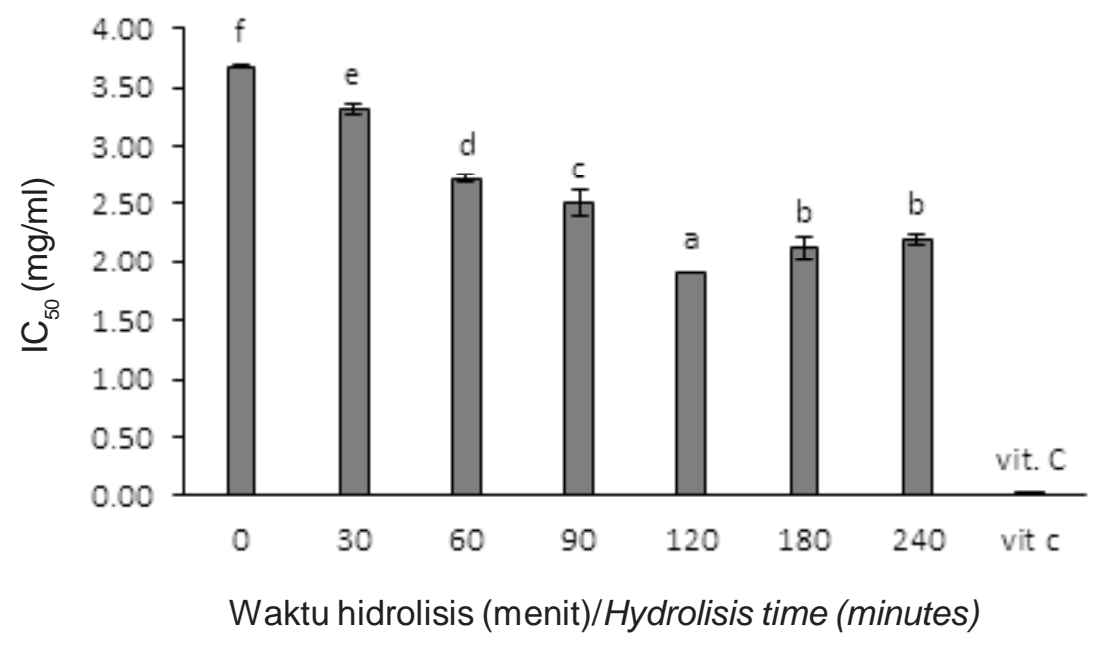

Keterangan/Note :

0 menit/0 minute : tanpa enzim/without enzyme

$\mathrm{IC}_{50}$ vit.C $=0.01 \mathrm{mg} / \mathrm{ml}$

Gambar 5. Aktivitas penghambatan radikal bebas DPPH peptida kolagen.

Figure 5. DPPH free radical inhibition activity of collagen peptide. 
Aktivitas antioksidan peptida kolagen dipengaruhi oleh beberapa faktor, di antaranya adalah : komposisi, struktur dan hidrofobisitas asam amino penyusun peptida (Kim et al., 2001; Li et al., 2007), jenis enzim penghidrolisis kolagen (Qian et al., 2008) yang menentukan ukuran dan sekuen peptida, dan bobot molekul peptida (Yang et al., 2008; Gómez-Guillén et al., 2010; Wang et al., 2013). Kim et al. (2001), menyatakan bahwa kandungan asam amino hidrofobik yang tinggi di dalam peptida dapat meningkatkan kelarutannya di dalam lemak, sehingga meningkatkan aktivitas antioksidasinya. Hidrolisis gelatin menggunakan enzim alkalase menghasilkan peptida gelatin yang memiliki aktivitas antioksidan lebih tinggi dibandingkan dengan penggunaan enzim kolagenase, pepsin, tripsin, chymotripsin, papain maupun neutrase (Qian et al., 2008). Sementara itu Fan et al. (2012) melaporkan bahwa aktivitas penghambatan radikal bebas DPPH hidrolisat protein dari tulang ikan tilapia menggunakan enzim tripsin menunjukkan nilai $\mathrm{IC}_{50}$ sebesar $1,92 \mathrm{mg} / \mathrm{ml}$, setelah melalui ultrafiltrasi dengan cut off < 1kDa (Fan et al., 2012). Nilai ini sekitar 2,8 kali lebih tinggi dibandingkan kontrol positif glutathione yaitu sebesar $0,69 \mathrm{mg} / \mathrm{ml}$. Hasil penelitian Wang et al. (2013) terhadap peptida kolagen murni dari tulang ikan croceine croaker (Pseudosciaena crocea) yang dihidrolisis menggunakan enzim tripsin dan pepsin, menunjukkan aktivitas penghambatan radikal bebas DPPH yang kuat, dengan nilai $I C_{50} 0,283$ $\mathrm{mg} / \mathrm{ml}$ pada konsentrasi yang sama dengan vitamin C, yaitu $5 \mathrm{mg} / \mathrm{ml}$. Peptida kolagen dengan bobot molekul 463,4070 Da ini memiliki urutan asam amino Gly-Phe-Pro-Ser-Gly.

\section{KESIMPULAN}

Aktivitas penghambatan ACE tertinggi terdapat pada peptida kolagen yang dihasilkan dari hidrolisis kolagen selama 180 menit, yaitu sebesar 82,31\% pada konsentrasi $15 \mathrm{mg} / \mathrm{ml}$. Aktivitas antioksidan paling kuat dihasilkan dari waktu hidrolisis 120 menit, dengan nilai $I_{50}$ sebesar $1,92 \mathrm{mg} / \mathrm{ml}$. Namun demikian, aktivitas penghambatan ACE maupun aktivitas antioksidan peptida kolagen ini masih lebih rendah dibandingkan dengan kontrol positif, yaitu masing-masing captopril dan vitamin C.

\section{UCAPAN TERIMA KASIH}

Ucapan terima kasih disampaikan kepada Balai Besar Penelitian dan Pengembangan Pengolahan Produk dan Bioteknologi Kelautan dan Perikanan, Jakarta Pusat atas sponsor yang telah diberikan dengan dana APBN tahun 2014/2015.

\section{DAFTAR PUSTAKA}

Abedin, M.D.Z., Karim, A.A., Latif, A.A., Gan, C.Y., Ghazali, F.C., Zaman, W., Hossain, M.D.M., Ahmed, F., Absar, N., \& Sarker, M.D.Z.I. (2013). Physicochemical and biochemical properties of pepsin solubilized collagen isolated from the integrument of sea cucumber (Stichopus vastus). Journal of Food Processing and Preservation.

Andirinasti, W.A. (2012). Uji manfaat ekstrak kolagen kasar dari Teripang Stichopus hermanii sebagai bahan pelembab kulit. Tesis. Fakultas MIPA, Universitas Indonesia.

Arihara, K., Nakashima, Y., Mukai, T., Ishikawa, S., \& Itoh, M. (2001). Peptide inhibitor for angiotensin-I converting enzyme from enzymatics hydrolisates of porcine skeletal muscle proteins. Meat Science, 57, 319-324.

Bordbar, S., Anwar, F., \& Nzamid, S. (2011). High-value components and bioactives from sea cucumbers for functional foods-A review. Mar. Drugs, 9, 1761-1805.

Cui, F.X., Xe, C.H., Li, Z.J., Zhang, Y.Q., Dong, P., Fu, X.Y., \& Gao, X. (2007). Characterization and subunit composition of collagen from the bodywall of sea cucumber Stichopus japonicus. Food Chemistry, 100, 1120-1125.

Du, L., Fang, M., Wu H., Xie J., Wu, Y., Li, P., Zhang, D., Huang, Z., Xia, Y., Zhou, L., \& Wei, D. (2013). A novel angiotensin-I converting enzyme inhibitory peptide from Phascolosoma esculenta water soluble protein hydrolysate. Journal of Functional Food, 5, 475-483.

Fan, J., He, J., Zhuang Y., \& Sun, L. (2012). Purification and identification of antioxidant peptides from enzymatic hydrolysates of tilapia (Orechromis niloticus) frame protein. Molecules, 17, 12836-12850.

Gimenez, B., Aleman, A., Montero, P., \& Gomez-Guillen, M.C. (2009). Antioxidant and functional properties of gelatin hydrolysates obtained from skin of sole and squid. Food Chemistry, 114, 976-983.

Ghufran, H. \& Kordi, K. (2010). Cara gampang membudidayakan teripang. Lily Publisher. Yogyakarta.

Haslaniza, H., Askat, M.Y., Wan., Aida, W.M., \& Mamot, S. (2010).The effect of enzyme concentration, temperature and incubation time of nitrogen content and degree of hydrolysis of protein precipitate from cockle (Anadara granosa) meat wash water. International Food Research Journal, 17, 147-152.

Jimsheena, V.K. \& Gowda, L.R. (2010). Arachin derived peptides as selective angiotensin I-converting enzyme (ACE) inhibitors: Structure-activity relationship. Peptides, 31, 1165-1176.

Kapel, R., Rahou, E., Lecouturier, D., Guillochon, D., \& Dhulster, D. (2006). Characterization of an antihypertensive peptide from an alfalfa white protein hydrolysates produced by continuous enzymatic membrane reactor. Process Biochemistry, 41, 19611966.

Kim, S.R. \& Byun, H.G. (2012). The novel angiotensin I converting enzyme inhibitory peptide from rainbow 
trout muscle hydrolysates. Fisheries Aquaculture Science, 15(3), 183-190.

Laemmli, U.K. (1970). Cleavage of structural protein during the assembly of the head of bacteriophage T4. Nature, 227, 680-685

Li, B., Chen, F., Wang, X., Ji, B. \& Wu, Y. (2007). Isolation and identification of antioxidative peptides from porcine collagen hydrolysate by consecutive chromatography and electrospray ionization-mass spectrometry. Food Chemistry, 102(4), 1135-1143.

Li, Y., Li, X., Lee, U.K., Kang, J.S., Choi, D.H., \& Son, B.W. (2006). A new radical scavenging anthracene glycoside, asperfavin ribofuranoside, and polyketides from a marine isolate of the fungus microsporum. Chemistry. Pharmaceutical Buletin, 54(6), 882-883.

Liu, Z., Alexandria, C.M., Oliveira., \& Su, Y.C. (2010). Purification and characterization of pepsin solubilized collagen from skin and connective tissue of giant red sea cucumber (Parastichopus californicus). Journal of Agriculture Food Chemistry, 58, 1270-1274.

Lowry, O.H., Rosebrough, N.J., Farr, A.L., \& Randal, R.J. (1951). Protein Measurement with The Folin Phenol Reagent. Department of pharmacology, Washington University School of Medicine, St. Louis, Misssouri.

Ovissipour, M., Benjakul, S., Safari, R., \& Motamedzadegan, A. (2010). Fish protein hydrolysates production from yellowfin tuna Thunnus albacores head using alcalase and protamex. International Aquatic Research, 2, 87-95.

Park, S.Y., Hee, K.L., Seogjae, L., Hyeong, C.H., Somi, K.C., \& Moonjae, C. (2011). Pepsin solubilized collagen (PSC) from red sea cucumber (Stichopus japonicus) regulates cell cycle and fibronectin synthesis in HaCaT cell migration. Food Chemistry, $11,032$.

Popov, A., Artyukov, A., Krivoshapko, O., \& Kozlovskaya, E. (2013). Biological activities of collagen peptides obtained by enzymic hydrolysis from far-eastern holothurians. American Journal of Biomedical and Life Sciences. 1(1): 17-26. Retrieved from http:// www.sciencepublishinggroup.com/j/ajbls.

Qian, Z.J., Jung, W.K., Byun, H.G., \& Kim, S.K. (2008). Protective effect of an antioxidant peptide purified from gastrointestinal digest of oyster, Crassostrea gigas agains free radical induced DNA damage. Bioresource Technology, 99, 3365-3371.

Saito, M., Kunisaki, N., Urano., \& Kimura, S. (2002). Collagen as the major edible component of sea cucumber (Stichopus japonicus). Journal of Food Science, 67, 4.

Siddiqui, Y.D., Arief, E.M., Yusoff, A., Suzina, A.H., and Abdullah, S.Y. (2013). Isolation of pepsin-solubilized collagen (PSC) from crude collagen extracted from body wall of sea cucumber (Bohadschia spp.). Int $J$ Pharm Pharm Sci., 5(2), 555-559.
Silvestre, M.P.C., Morais, H.A., Silva,V.D., Silva, M.R., \& Grau. (2013). Degree of hydrolysis and peptide profile of whey proteins using pancreatin. Journal Brazilian Society and Food Nutrition. Sp., 38(3), 278-290.

Vo, T.S., Ngo, D.H., Kim, J.A., Ryu, B., \& Kim, S.K. (2011). An antihypertensive peptide from tilapia gelatin diminishes free radical formation inmurine microgial cells. Journal of Agricultural and Food Chemistry. 59, 12193-12197.

Wang, B., Li, L., Chi, C.F., Ma, J.H., Luo, H.Y., \& Xu, Y.F. (2013). Purification and characterization of a novel antioxidant peptide derived from blue mussel (Mytillus edulis) protein hydrolysates. Food Chemistry. 138, 1713-1719.

Wang, B., Wang, Yu-Mei, Chi, Chang-Feng, Luo, HongYu, Deng, Shang-Gui, \& Ma, Jian-Yin. (2013). Isolation and Characterization of Collagen and Antioxidant Collagen Peptides from Scales of Croceine Croaker (Pseudosciaena crocea). Mar Drugs, 11(11), 4641-4661. doi: 10.3390/ md11114641

Widodo, A. 2011. Budidaya teripang, khasiat dan cara olah untuk pengobatan. Pustaka Baru Press. Yogyakarta.

Wijesekara, I., Qian, Z.J., Ryu, B., Ngo, D.H., Kim, S.K. 2011. Purification and identification of antihypertensive peptides from seaweed pipefish (Syngnathus schelegeli) muscle protein hydrolysates. Food Research International, 44, 703707.

Yang, J., Ho, H., Chu, Y., \& Chow, C. (2008). Characteristic and antioxidant activity of retorted gelatin hydrolysates from cobia (Rachycentron canadum) skin. Food Chemistry, 110(1), 128-136.

You, L., Zhao, M., Regenstein, J.M., \& Ren, J. (2010). Purification and identification of antioxidative peptides from loach (Misgurnus anguilicaudatus) protein hydrolysates by consecutive chromatography and electrosray ionization-mass spectrometry. Food Research International, 43, 1167-1173.

Zhang, Y., Olsen, K., Grosi, A., \& Otte, J. (2013). Effect of pretreatment on enzymes hydrolysis of bovine collagen and formation of ACE-inhibitory peptides. Food Chemistry, 141, 2343-2354.

Zhang, J., Zhang, H., Wang, L., Ghuo, X., Wang, X., \& Yao, $H$. (2009). Antioxidant activities of the rice endosperm protein hydrolysates identification of the active peptide. European Food Research Technology, 229, 709-719

Zhong, M., Chen, T., Hu, C., \& Ren, C. (2015). Isolation and characterization of collagen from body wall of sea cucumber Stichopus monotuberculatus. Paper accepted in Journal of Food Science.

Zhou, X., Wang, C. \& Jiang, A. (2012). Antioxidant peptides isolated from sea cucumber Stichopus japonicus. Eur Food Res Technol., 234, 441-447. 